\title{
Emergence of $\mathrm{CO}_{2}$ electrolyzers including supported molecular catalysts
}

\author{
Kristian Torbensen ${ }^{1}$, Benjamin Boudy ${ }^{1}$, Dorian Joulié, ${ }^{1,2}$ Niklas von Wolff ${ }^{1}$ and Marc \\ Robert*,1,3 \\ ${ }^{1}$ Université de Paris, Laboratoire d'Electrochimie Moléculaire, CNRS, F-75013 Paris, France. \\ ${ }^{2}$ Department of Chemistry, University of British Columbia, Vancouver, British Columbia V6T \\ 1Z1, Canada. ${ }^{3}$ Institut Universitaire de France (IUF), F-75005 Paris, France. \\ *robert@u-paris.fr
}

\begin{abstract}
With access to cheap, sustainable electricity, electrocatalysis is a promising technology for converting electric power into storable chemical fuels or value added chemical compounds. This has sparked the development of electrocatalysts that need to operate at high product selectivity and high energy efficiency. Electrocatalytic alcohol oxidation, oxygen activation, nitrogen and carbon dioxide reduction are examples of reactions with a huge industrial potential. Notably, electrocatalytic reduction of carbon dioxide has recently developed as a favourable pathway to convert this greenhouse gas into value added chemicals and fuels. Earth abundant metals stabilized by carbon/nitrogen macrocycle ligands are well-known efficient and selective catalysts for the electrochemical reduction of $\mathrm{CO}_{2}$ in homogeneous conditions. Recently, such catalysts have also been used in supported conditions and implemented in flow cell electrolyzers, showing promising performances. This review provides a synopsis for the evolution of $\mathrm{CO}_{2}$ electrolyzers employing molecular catalysts.
\end{abstract}

\section{Keywords}

$\mathrm{CO}_{2}$ catalysis, molecular catalysts, flow cells, electrolyzers.

\section{Introduction}

Emission of carbon dioxide $\left(\mathrm{CO}_{2}\right)$ to an alarming atmospheric level has driven the search for materials capable of catalysing the $\mathrm{CO}_{2}$ reduction reaction $\left(\mathrm{CO}_{2} \mathrm{RR}\right)$. Combined with renewable energy, the electrocatalytic conversion of $\mathrm{CO}_{2}$ is an appealing method for storing energy in the form of carbon-based fuels (e.g. methane, methanol and ethanol),[1] or for generating commodity chemicals (e.g. carbon monoxide, formic acid, ethanol and ethylene).[2, 3] With power-to-X approach employing $\mathrm{CO}_{2}$ electrolyzers, ideally situated at local emission sources, 
such renewable energy driven $\mathrm{CO}_{2}$ conversion will help mitigating $\mathrm{CO}_{2}$ emission and in addition generate valuable chemical feedstocks. With more and more countries taxing $\mathrm{CO}_{2}$ emission (currently the tax per emitted tonne of $\mathrm{CO}_{2}$ is around $150 €$ in many EU countries, a number that will likely increase in the future),[4] there is a growing economic incentive for the industry and governments to invest in the development of $\mathrm{CO}_{2}$ electrolyzer plants. However, environment friendly electro-materials with high efficiencies are a prerequisite. Regarding the efficiency criteria, there is a consensus that electrolyzers must operate at current density $>200$ $\mathrm{mA} \mathrm{cm} \mathrm{cm}^{-2}$, with the area measure referring to the geometric surface of the electrolyzer cathode.[5-7] Until recently, this value has only been approached with copper or precious metal catalysts such as silver and gold employed in gas diffusion $\mathrm{CO}_{2}$ electrolyzers (see Table 1 for a summary of the state-of-the-art metrics). To reach higher performances, with respect to both current density and product selectivity, thorough mechanistic studies of the electrocatalytic $\mathrm{CO}_{2} \mathrm{RR}$ are necessary. However, metallic coatings and nanoparticles typically include different grain boundaries, crystal defects, oxygen derived species and various open facets exposed to the reacting $\mathrm{CO}_{2} \cdot[8,9]$ To elucidate the structure-activity relationship of such complex surfaces, one must know in detail what are the active sites and the density of states responsible for the electrocatalytic $\mathrm{CO}_{2}$-to-product conversion. Operando characterization methods are developing fast, albeit a tedious task regarding the nanometric scale of the active sites combined with beam attenuation in the electrolyte solution in operating electrolyzers.[10, 11]

\section{Molecular catalysts provide well-defined and tunable reaction centres}

When discrete molecules are employed as catalysts, mechanistic studies become more accessible. With activated molecules being all identical, catalytic activity would result in a characteristic response. Solution based spectro-electrochemical methods, cyclic voltammetry $(\mathrm{CV})$ and preparative electrolysis have proven powerful tools for investigating
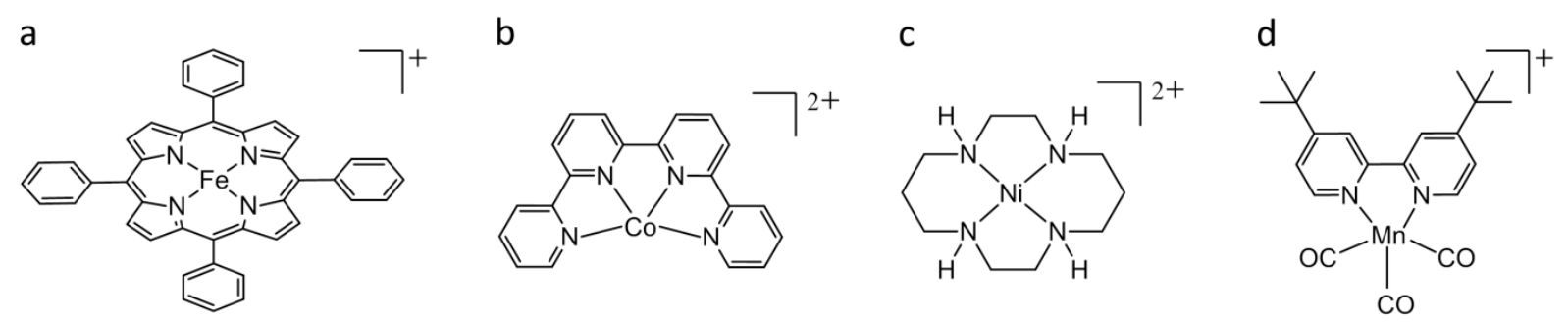

Figure 1. Selective electrocatalysts for the 2e- reduction of $\mathrm{CO}_{2}$. (a) Iron tetraphenyl porphyrin, (b) Cobalt quaterpyridine, (c) Nickel cyclam and (d) Manganese triscarbonyl di-tert-butyl bipyridine. 
structure-activity relationship of various molecular catalysts in homogeneous conditions.[1214] Using these relatively easy to implement electrochemical methods, catalytic Tafel plots relating the turnover frequency (TOF) to the applied overpotential can be obtained, providing a benchmark method for quantifying the catalytic activity and enabling comparison between different metal centres and ligand structures.[15] The most active molecular catalysts reported share a metal center coordinated to a tetradentate nitrogen-donor based ligand, such as porphyrins, phthalocyanines, polypyridines and cyclams, some examples being shown in Figure 1.[16-22] Further insight on homogenous electrocatalyzed $\mathrm{CO}_{2} \mathrm{RR}$ using molecular catalysts can be found in recent reviews.[2, 3, 23]

Albeit homogeneous conditions are appropriate for deciphering the intrinsic activity of molecular catalysts, there are several barriers toward high substrate-to-product conversion efficiency. Main limitations consist in catalyst and substrate mass transfer to the electrode, and catalyst solubility which constrains the choice of electrolyte solution (e.g. few catalysts are soluble in water). Immobilization of the catalyst onto a conductive material can help solving these issues.

\section{Supported molecular catalysts for the $\mathrm{CO}_{2} \mathrm{RR}$, an emerging approach with remaining challenges}

The main strategies for catalyst immobilization are outlined in Figure 2.[24] They include physical adsorption, chemical bonding and integration into 3-D frameworks. Physical adsorption occurs via $\pi-\pi$, Van der Waals or electrostatic interactions between the molecular catalyst and the conductive support. With most reported molecular catalysts bearing conjugated organic ligands, $\pi-\pi$ interactions are advantageous for immobilization on conjugated and

a

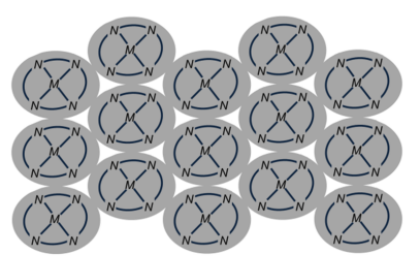

Molecular catalysts physisorbed on a support b

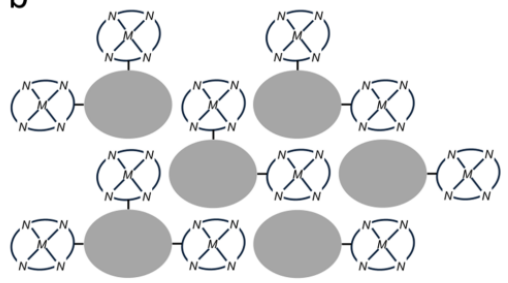

Molecular catalysts covalently bonded to a support

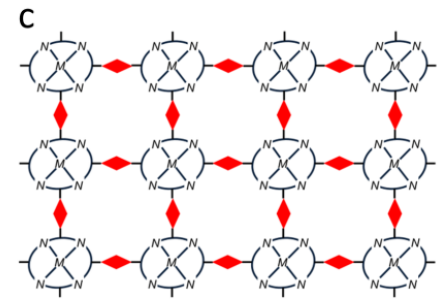

Molecular catalysts linked in an organic framework

Figure 2. Strategies for the immobilization of molecular catalysts on conductive supports. (a) Physisorption via catalyst-support interactions, (b) chemisorption via catalyst-support linkage and (c) integration of the catalyst in a conjugated organic framework. 
conductive support materials such as carbon nanotubes,[18] graphene[25] and carbon black particles.[26] Direct chemical bonding (or covalent grafting) of the catalyst to the support has been investigated, such as phosphonate linkage to a metal oxide[27, 28] or via diazonium and amide chemistry.[29] Such approach was developed by Zhu et al.,[30] for grafting a Co protoporphyrin at carbon nanotubes through covalent linkage between the support and the cobalt atom of the complex. It led to a current density for $\mathrm{CO}_{2}$ reduction in an $\mathrm{H}$-cell close to the substrate mass transfer limiting value (vide infra). In comparison with homogeneous conditions, enhanced catalytic activity upon catalyst immobilization has been observed in some cases. [31]

Integration of the catalyst into metal organic frameworks is another strategy providing porous materials with electronically addressed well-defined catalytic centres, although conductivity of such materials remains an issue.[32-35] The above mentioned examples have been beneficial in establishing a better comprehension of the $\mathrm{CO}_{2} \mathrm{RR}$ in supported conditions and for the development of catalytic materials,[36] but mechanistic studies remain scarce and need to be vigorously developed. Additional difficulties toward this goal arise from the fact that only a fraction of the supported catalysts is active within films (the exact active surface concentration is not easily assessed). Moreover, the exact degree of electronic interaction between the molecules and the conductive support may vary from weak to strong coupling which may

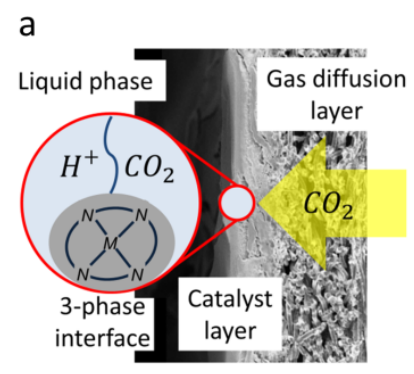

d

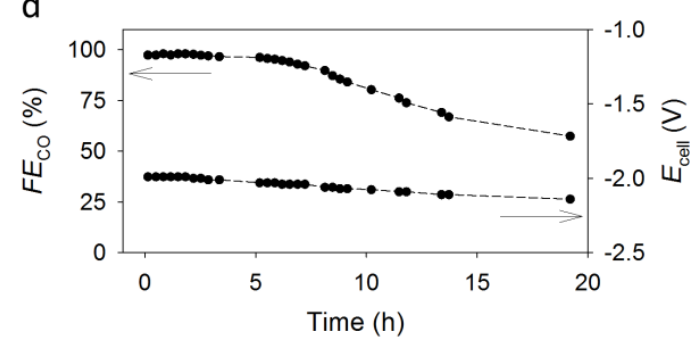

b

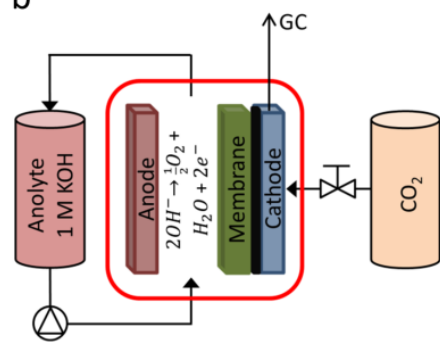

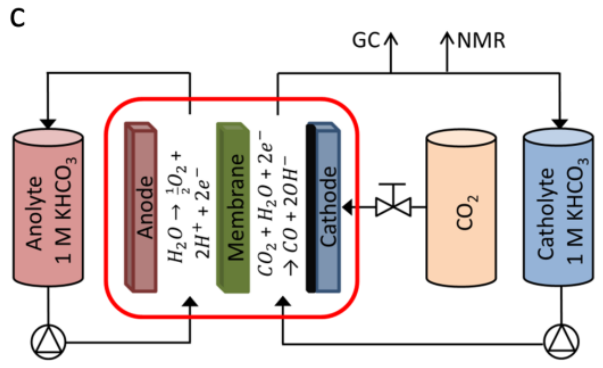

e

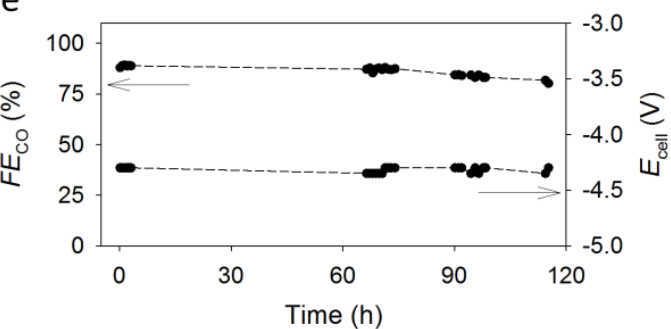

Figure 3. (a) Schematic representation of the 3-phase (solid-liquid-gas) reaction interface in a gas diffusion electrode (GDE). (b) Sketch of a zero-gap electrolyzer without catholyte flow. (c) Sketch of an electrolyzer with both anolyte and catholyte flow. (d and e) Stability test of the cobalt phthalocyanine catalyst $\mathrm{CoPc}$ at constant current density of $50 \mathrm{~mA} \mathrm{~cm} \mathrm{~cm}^{-2}$ in a zero-gap electrolyzer and in a flow cell electrolyzer, respectively. 
impact both the catalytic activity and mechanisms. Practical applications are also still limited. Due to the low solubility of $\mathrm{CO}_{2}$ in aqueous media ( $\sim 34 \mathrm{mM}$ at $298 \mathrm{~K}$ and $1 \mathrm{~atm}$.), semi-infinite boundary diffusive models predict a limiting current density of $\sim 35 \mathrm{~mA} \mathrm{~cm}$ cor $^{-2}$ for conversion at planar electrodes.[37]

As mentioned in the introduction, electrolyzers mounted with vapour-fed gas diffusion electrodes (GDEs) and employing solid state precious metal catalysts are now reaching commercially relevant current densities for the $\mathrm{CO}_{2} \mathrm{RR}$. Such performance was made possible by increased mass transfer in the gas phase combined with a high density of catalytic sites at the 3-phase interface in the GDE, as illustrated in Figure 3a. Taking inspiration from such design may provide a route for implementing molecular catalysts made of earth abundant elements in electrolyzers meeting commercial requirements.

\section{Illustrative advances and opportunities in using supported molecular catalysts in $\mathrm{CO}_{2}$ electrolyzers}

The use of molecular catalysts such as porphyrins and phthalocyanines at gas diffusion electrodes has been pioneered in the 80 's and 90's, with current densities reaching a few tens of $\mathrm{mA} \mathrm{cm}^{-2}$.[38-40] Implementation of commercially available cobalt phthalocyanine (CoPc, Figure 4a) in a zero-gap electrolyzer was recently reported (Figure 3b).[41] The GDE employed was manufactured by spray coating an ink comprising carbon black supported CoPc onto hydrophobic carbon paper, and subsequently deposited at an anion exchange membrane. With a constant flow of humidified $\mathrm{CO}_{2}$ to the GDE, performances (Faradaic efficiency for $\mathrm{CO}$ $\left(\mathrm{FE}_{\mathrm{CO}}\right)$ and cell potential) were evaluated at current densities ranging from 25 to $200 \mathrm{~mA} \mathrm{~cm}{ }^{-2}$. $\mathrm{FE}_{\mathrm{CO}}>95 \%$ was maintained at current densities up to $150 \mathrm{~mA} \mathrm{~cm}{ }^{-2}$, for which the cell potential was $2.43 \mathrm{~V}$ (energy efficiency (EE) of 52\%). At higher current densities, FE Co dropped rapidly, reaching $60 \%$ at $200 \mathrm{~mA} \mathrm{~cm}^{-2}$. Such decrease is likely a consequence of the generation of hydroxide ions within the GDE (vide infra). The stability of the CoPc catalyst in the zero-gap electrolyzer was investigated at a current density of $50 \mathrm{~mA} \mathrm{~cm}{ }^{-2}$. As shown in Figure $3 \mathrm{~d}, \mathrm{FE}_{\mathrm{CO}}$ could be maintained above $90 \%$ for more than 8 hours, corresponding to $>4.000$ catalytic cycles (CCs) for each active site. Hereafter, the $\mathrm{FE}_{\mathrm{GO}}$ dropped quite rapidly. Hereafter, a gradual decrease reaching $\sim 60 \%$ in the $\mathrm{FE}_{\mathrm{CO}}$ was observed. Lack of long term stability in this zero-gap configuration was mainly ascribed to the formation of potassium carbonate on the cathode flow plate, obstructing the free flow of $\mathrm{CO}_{2}$ to the GDE. This precipitation occurs when potassium ions cross the membrane from the anodic side and react with the carbonate, the latter being formed in large amounts with increasing current density.[42] Initial performance could be 
regenerated after disassembling the electrolyzer and washing the precipitated salt, indicating that no molecular degradation of the catalyst had occurred. This was further confirmed by incorporating the GDE in a flow cell electrolyzer with a continuous flow of an electrolyte solution $\left(0.5 \mathrm{M} \mathrm{NaHCO}_{3}\right)$ between the GDE and the membrane (Figure 3c). In such a configuration, a $\mathrm{FE}_{\mathrm{CO}}$ above $80 \%$ was maintained for $>100$ hours at a current density of $50 \mathrm{~mA}$ $\mathrm{cm}^{-2}$ (corresponding to $\sim 16000 \mathrm{CCs}$ ), with no significant change of $\mathrm{FE}_{\mathrm{CO}}$ and cell potential (Figure 3e). In this configuration, hydroxide ions are continuously removed by the electrolyte solution. However, this type of electrolyzer runs at lower EEs, due to an increased ohmic cell resistance.

CV studies of a cobalt phthalocyanine bearing one trimethyl ammonium group and three tertbutyl groups appended on the phthalocyanine macrocycle (CoPc2, Figure $4 \mathrm{~b}$ ) showed an $25 \%$ increase in the catalytic activity towards $\mathrm{CO}_{2}$-to-CO conversion compared to $\mathrm{CoPc}$.[43] It was mainly ascribed to the through-space stabilizing effect on the $\mathrm{Co}(\mathrm{I})-\mathrm{CO}_{2}{ }^{--}$adduct exerted by the positive charge on the quaternary ammonium appended to the macrocycle, as previously reported for an iron porphyrin.[16] CoPc2 was incorporated at a GDE which was inserted in a flow cell configuration using $1 \mathrm{M} \mathrm{KOH}$ as electrolyte solution. With a catalyst amount of only $0.2 \mathrm{mg} \mathrm{cm}^{-2}$, a partial current density for $\mathrm{CO}\left(\mathrm{j}_{\mathrm{CO}}\right)$ of $112 \mathrm{~mA} \mathrm{~cm}{ }^{-2}$ (with $96 \%$ selectivity and an overpotential $\left(E_{\text {electrode }}-E^{0} \mathrm{CO}_{2} / \mathrm{CO}\right)$ of $\left.610 \mathrm{mV}\right)$ was maintained for 3 hours. Each catalyst site endured $29000 \mathrm{CCs}$ providing a turn over frequency of $2.7 \mathrm{~s}^{-1}$. At an overpotential of $810 \mathrm{mV}$, a jco of $165 \mathrm{~mA} \mathrm{~cm}^{-2}$ was reached (selectivity of 94\%), matching state-of-the-art Ag based catalysts so far reported with respect to both current density and CO selectivity. Stability test at a current density of $75 \mathrm{~mA} \mathrm{~cm}^{-2}$ provided an average selectivity of $94 \%$ for more than 10 hours. Post-electrolysis examination of the GDE (Co K-edge XANES spectroscopy) showed no degradation of the catalyst.

a

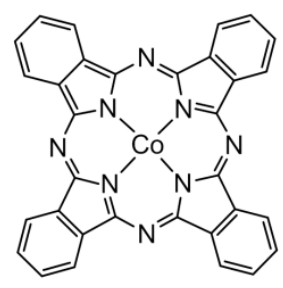

CoPc b

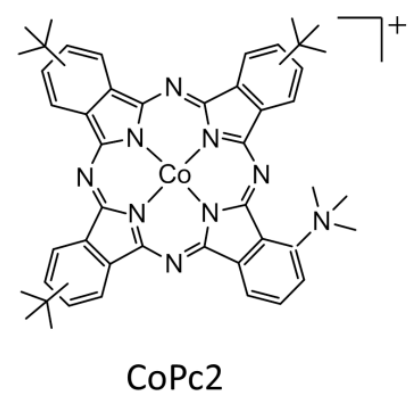

C

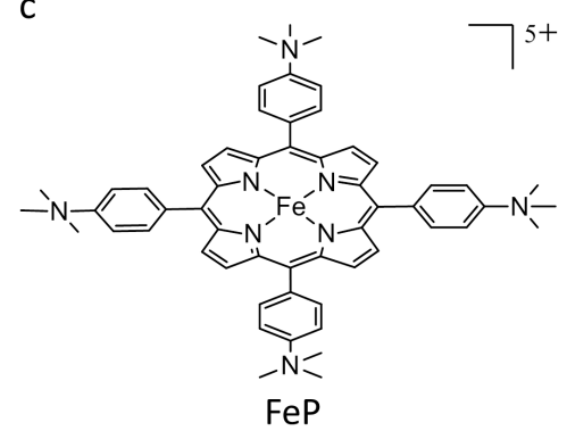

Figure 4. (a) Cobalt phthalocyanine ( $\mathrm{CoPc})$, (b) substituted cobalt phthalocyanine (CoPc2), (c) substituted tetraphenyl iron porphyrin $(\mathrm{FeP})$. 
Employing a cyano substituted CoPc adsorbed on carbon nanotubes, deposited at a GDE and inserted in a flow cell, Lu et al.[44] obtained a j $\mathrm{CO}$ of $31 \mathrm{~mA} \mathrm{~cm}^{-2}$ with a $\mathrm{FE}_{\mathrm{CO}}$ of $94 \%(560 \mathrm{mV}$ overpotential). A maximum j $\mathrm{j}_{\mathrm{CO}}$ of $82 \mathrm{~mA} \mathrm{~cm}^{-2}$ was reached, with a $\mathrm{FE}_{\mathrm{CO}}$ of $\sim 50 \%$. Further increase in the total current density $\left(\mathrm{j}_{\text {total }}\right)$ resulted in hydrogen production mainly. At FE $\mathrm{CO}_{\mathrm{CO}}$ ca. $90 \%$ and at a current density close to $40 \mathrm{~mA} \mathrm{~cm}{ }^{-2}$, performances were maintained during $10 \mathrm{~h}$.

Table 1. Metrics for state-of-the-art $\mathrm{CO}_{2}$-to- $\mathrm{CO}$ metal and supported molecular catalysts.

\begin{tabular}{|c|c|c|c|c|c|}
\hline $\begin{array}{c}\text { Catalyst/ } \\
\text { support }\end{array}$ & $\begin{array}{c}\text { Main product and partial } \\
\text { current density }\left(\mathrm{mA} \mathrm{cm}^{-2}\right)\end{array}$ & FE (\%) & $\begin{array}{c}\mathrm{E} \\
\text { (V vs RHE) }\end{array}$ & Electrolyte & Ref. \\
\hline $\mathrm{Ag} / \mathrm{PTFE}^{\mathrm{a}}$ grid & $\mathrm{CO} / 150$ & 90 & -0.7 & $1 \mathrm{M} \mathrm{KOH}$ & {$[47]$} \\
$\mathrm{Au} / \mathrm{MWCNT}^{\mathrm{b}}$ & $\mathrm{CO} / 158$ & 85 & -0.55 & $2 \mathrm{M} \mathrm{KOH}$ & {$[48]$} \\
$\mathrm{Cu} / \mathrm{CP}^{\mathrm{c}}$ & $\mathrm{C}_{2} \mathrm{H}_{4} / 473$ & 63 & -0.67 & $3.5 \mathrm{M} \mathrm{KOH}^{\mathrm{d}}$ & {$[49]$} \\
$\mathrm{Ni} \mathrm{SA} / \mathrm{CF}^{\mathrm{e}}$ & $\mathrm{CO} / 308$ & 88 & -1.0 & $0.5 \mathrm{M} \mathrm{KHCO}_{3}$ & {$[50]$} \\
$\mathrm{CoPc} 2 / \mathrm{CNP}^{\mathrm{f}}$ & $\mathrm{CO} / 165$ & 94 & -0.92 & $1 \mathrm{M} \mathrm{KOH}$ & {$[43]$} \\
$\mathrm{FeP} / \mathrm{CNP}^{\mathrm{f}}$ & $\mathrm{CO} / 152$ & 98 & -0.59 & $1 \mathrm{M} \mathrm{KOH}$ & {$[45]$} \\
\hline
\end{tabular}

${ }^{\mathrm{a}}$ Polytetrafluoroethylene. ${ }^{\mathrm{b}}$ Multi-walled carbon nanotubes. ${ }^{\mathrm{c}}$ Carbon paper. ${ }^{\mathrm{d}}$ Includes $5 \mathrm{M} \mathrm{KI}$.

e Single atom catalysts at carbon fiber. ${ }^{\mathrm{f}}$ Carbon nanoparticles.

In addition to tuning the catalyst structure, various parameters have been shown to influence cell performance. Using a substituted iron porphyrin (FeP, Figure 4c) based GDE, the cell temperature $\left(\mathrm{T}_{\text {cell }}\right)$ played a significant role on the catalytic performance.[45] At neutral $\mathrm{pH}$ $\left(\mathrm{CO}_{2}\right.$ saturated $0.5 \mathrm{M} \mathrm{NaHCO}_{3}$ electrolyte solution), a 39\% current density increase was obtained by increasing $\mathrm{T}_{\text {cell }}$ from 24 to $40{ }^{\circ} \mathrm{C}$ without compromising the $\mathrm{CO}$ selectivity. At 40 ${ }^{\circ} \mathrm{C}$, a current density of $50 \mathrm{~mA} \mathrm{~cm}{ }^{-2}$ was maintained for 3 hours with an average CO selectivity as high as $98.6 \%$. In addition, the overpotential was lowered by $300 \mathrm{mV}$ compared to that needed to achieve the same current density at $24{ }^{\circ} \mathrm{C}$, illustrating the positive impact of such moderate temperature increase. As it has been shown for solid metal based catalysts,[46] the electrolyte cation size has a significant impact on the electrochemical $\mathrm{CO}_{2} \mathrm{RR}$. Larger cations such as $\mathrm{Cs}^{+}$induce a higher surface charge density at the cathode and favour the $\mathrm{CO}_{2} \mathrm{RR}$ with stronger $\mathrm{CO}_{2}$ affinity for the electrode surface. The same effect was observed for $\mathrm{FeP}$ immobilized on a carbon support in a flow cell with various bicarbonate species. At a fixed current density of $50 \mathrm{~mA} \mathrm{~cm}{ }^{-2}$, a significant lowering of the overpotential (and hence an increased energy efficiency) was observed with increasing cation size in the order $\mathrm{Cs}^{+}>\mathrm{K}^{+}>$ $\mathrm{Na}^{+}$as well as concomitant increase of selectivity. In alkaline conditions $(1 \mathrm{M} \mathrm{KOH})$, this 
catalyst displayed promising metrics. At $470 \mathrm{mV}$ overpotential, a current density of $155 \mathrm{~mA}$ $\mathrm{cm}^{-2}$ was obtained with a CO selectivity $>98 \%$, better than noble metal catalysts performances.[47] At $50 \mathrm{~mA} \mathrm{~cm}^{-2}$, a remarkably low overpotential of $120 \mathrm{mV}$ was maintained over 3 hours, with $99.8 \% \mathrm{CO}$ selectivity and $57 \% \mathrm{EE}$, with only hydrogen as a trace by-product.

\section{Conclusions}

Molecular catalysts implemented in $\mathrm{CO}_{2}$ electrolyzers have shown promising performances, comparable to those of solid state precious metals. Their unexpected ability to maintain high selectivity at high rates for $\mathrm{CO}_{2}$-to- $\mathrm{CO}$ conversion opens new perspectives, although several aspects need to be addressed in order to meet industrial demands, in particular regarding long term stability at high current densities. Mechanistic studies so as to understand the exact catalytic mechanisms and degradation pathways are, in combination with engineering efforts to overcome cathode blockage, key to improve electrolyzer performances. Furthermore, turnover frequencies so far obtained in flow cells are still several orders of magnitude lower than the values reported for the same catalysts in homogeneous conditions. Better control and understanding of catalyst insertion and dispersion within GDEs is a pre-requisite to increase performances, since it may lead to optimization of both electronic addressability and substrate interaction at the catalytic sites. Reported results for the $\mathrm{CO}_{2}$-to-CO conversion will hopefully stimulate the development of improved $\mathrm{CO}_{2}$ electrolyzers involving molecular catalysts, not only for CO production but also to get more reduced products such as methanol and methane, as well as $\mathrm{C}_{2}$ and $\mathrm{C}_{2+}$ species.

\section{Acknowledgement}

Partial financial support from Air Liquide and from the Institut Universitaire de France (IUF) are gratefully acknowledged.

\section{References}

[1] Whipple DT, Kenis PJA. Prospects of $\mathrm{CO}_{2}$ Utilization via Direct Heterogeneous Electrochemical Reduction. The Journal of Physical Chemistry Letters. 2010;1:3451-8.

[2] Benson EE, Kubiak CP, Sathrum AJ, Smieja JM. Electrocatalytic and homogeneous approaches to conversion of $\mathrm{CO}_{2}$ to liquid fuels. Chemical Society Reviews. 2009;38:89-99.

[3] Costentin C, Robert M, Savéant J-M. Catalysis of the electrochemical reduction of carbon dioxide. Chemical Society Reviews. 2013;42:2423-36.

[4] Database of Institutional Comparison in Europe (DICE), www.cesifo.de.

[5] Verma S, Kim B, Jhong H-RM, Ma S, Kenis PJA. A Gross-Margin Model for Defining

Technoeconomic Benchmarks in the Electroreduction of $\mathrm{CO}_{2}$. ChemSusChem. 2016;9:1972-9. 
[6] Spurgeon JM, Kumar B. A comparative technoeconomic analysis of pathways for commercial electrochemical $\mathrm{CO}_{2}$ reduction to liquid products. Energy \& Environmental Science. 2018;11:1536-51. * [7] De Luna P, Hahn C, Higgins D, Jaffer SA, Jaramillo TF, Sargent EH. What would it take for renewably powered electrosynthesis to displace petrochemical processes? Science.

2019;364:eaav3506.

A techno-economic analysis allows for understanding of the technological, social-political and economic incentives necessary for the transition from a fossil energy stock relying society to a world based on renewable chemical (electro)synthesis.

[8] Clark EL, Ringe S, Tang M, Walton A, Hahn C, Jaramillo TF, Chan K, Bell AT. Influence of Atomic Surface Structure on the Activity of Ag for the Electrochemical Reduction of $\mathrm{CO}_{2}$ to $\mathrm{CO}$. ACS Catalysis. 2019;9:4006-14.

[9] Mezzavilla S, Horch S, Stephens IEL, Seger B, Chorkendorff I. Structure Sensitivity in the Electrocatalytic Reduction of $\mathrm{CO}_{2}$ with Gold Catalysts. Angewandte Chemie International Edition. 2019;58:3774-8.

[10] Firet NJ, Blommaert MA, Burdyny T, Venugopal A, Bohra D, Longo A, Smith Wa. Operando EXAFS study reveals presence of oxygen in oxide-derived silver catalysts for electrochemical $\mathrm{CO}_{2}$ reduction. Journal of Materials Chemistry A. 2019;7:2597-607.

[11] Heidary N, Ly KH, Kornienko N. Probing $\mathrm{CO}_{2}$ Conversion Chemistry on Nanostructured Surfaces with Operando Vibrational Spectroscopy. Nano Letters. 2019;19:4817-26.

*[12] Costentin C, Savéant J-M. Multielectron, Multistep Molecular Catalysis of Electrochemical Reactions: Benchmarking of Homogeneous Catalysts. ChemElectroChem. 2014;1:1226-36.

Establishment of catalytic Tafel plots (Turnover frequency $=f($ Electrode overpotential) $)$ for twoelectrons two-protons catalytic reaction processes from cyclic voltammetry experiments, allowing for rigorous comparison of intrinsic activities of homogeneous molecular catalysts.

[13] Azcarate I, Costentin C, Robert M, Savéant J-M. Dissection of Electronic Substituent Effects in Multielectron-Multistep Molecular Catalysis. Electrochemical $\mathrm{CO}_{2}$-to-CO Conversion Catalyzed by Iron Porphyrins. The Journal of Physical Chemistry C. 2016;120:28951-60.

[14] Cometto C, Chen L, Lo P-K, Guo Z, Lau K-C, Anxolabéhère-Mallart E, Fave C, Lau T-C, Robert M. Highly Selective Molecular Catalysts for the $\mathrm{CO}_{2}$-to-CO Electrochemical Conversion at Very Low Overpotential. Contrasting Fe vs Co Quaterpyridine Complexes upon Mechanistic Studies. ACS Catalysis. 2018;8:3411-7.

[15] Costentin C, Robert M, Savéant J-M. Molecular catalysis of electrochemical reactions. Current Opinion in Electrochemistry. 2017;2:26-31.

*[16] Azcarate I, Costentin C, Robert M, Savéant J-M. Through-Space Charge Interaction Substituent Effects in Molecular Catalysis Leading to the Design of the Most Efficient Catalyst of $\mathrm{CO}_{2}$-to-CO Electrochemical Conversion. J Am Chem Soc. 2016;138:16639-44.

Example of rational tuning of a catalyst ligand structure to accelerate the kinetics ('through space' effects) and decrease the thermodynamic cost ('through structure' effect). It led the most efficient homogeneous molecular electrochemical catalyst so far known for the $\mathrm{CO}_{2}$-to-CO conversion.

[17] Rønne MH, Cho D, Madsen MR, Jakobsen JB, Eom S, Escoudé É, Hammershøj HCD, Nielsen DU, Pedersen SU, Baik M-H, Skrydstrup T, Daasbjerg K. Ligand-Controlled Product Selectivity in Electrochemical Carbon Dioxide Reduction Using Manganese Bipyridine Catalysts. J Am Chem Soc. 2020;142:4265-75. 
[18] Wang M, Chen L, Lau T-C, Robert M. A Hybrid Co Quaterpyridine Complex/Carbon Nanotube Catalytic Material for $\mathrm{CO}_{2}$ Reduction in Water. Angewandte Chemie International Edition.

2018;57:7769-73.

[19] Froehlich JD, Kubiak CP. Homogeneous $\mathrm{CO}_{2}$ Reduction by Ni(cyclam) at a Glassy Carbon Electrode. Inorganic Chemistry. 2012;51:3932-4.

[20] Hawecker J, Lehn J-M, Ziessel R. Electrocatalytic reduction of carbon dioxide mediated by $\operatorname{Re}($ bipy $)(\mathrm{CO})_{3} \mathrm{Cl}$ (bipy = 2,2'-bipyridine). Journal of the Chemical Society, Chemical Communications. 1984:328-30.

[21] Khadhraoui A, Gotico P, Boitrel B, Leibl W, Halime Z, Aukauloo A. Local ionic liquid environment at a modified iron porphyrin catalyst enhances the electrocatalytic performance of $\mathrm{CO}_{2}$ to $\mathrm{CO}$ reduction in water. Chemical Communications. 2018;54:11630-3.

[22] Myren THT, Lilio AM, Huntzinger CG, Horstman JW, Stinson TA, Donadt TB, Moore C, Lama B, Funke HH, Luca OR. Manganese N-Heterocyclic Carbene Pincers for the Electrocatalytic Reduction of Carbon Dioxide. Organometallics. 2019;38:1248-53.

[23] Francke R, Schille B, Roemelt M. Homogeneously Catalyzed Electroreduction of Carbon Dioxide-Methods, Mechanisms, and Catalysts. Chem Rev. 2018;118:4631-701.

[24] Hu X-M, Pedersen SU, Daasbjerg K. Supported molecular catalysts for the heterogeneous $\mathrm{CO}_{2}$ electroreduction. Current Opinion in Electrochemistry. 2019;15:148-54.

[25] Choi J, Wagner P, Jalili R, Kim J, MacFarlane DR, Wallace GG, Officer DL. A Porphyrin/Graphene Framework: A Highly Efficient and Robust Electrocatalyst for Carbon Dioxide Reduction. Advanced Energy Materials. 2018;8:1801280.

[26] Tatin A, Comminges C, Kokoh B, Costentin C, Robert M, Savéant J-M. Efficient electrolyzer for $\mathrm{CO}_{2}$ splitting in neutral water using earth-abundant materials. Proceedings of the National Academy of Sciences. 2016;113:5526-9.

[27] Mohamed EA, Zahran ZN, Naruta Y. Efficient Heterogeneous $\mathrm{CO}_{2}$ to $\mathrm{CO}$ Conversion with a Phosphonic Acid Fabricated Cofacial Iron Porphyrin Dimer. Chemistry of Materials. 2017;29:7140-50.

[28] Wang Y, Marquard SL, Wang D, Dares C, Meyer TJ. Single-Site, Heterogeneous Electrocatalytic Reduction of $\mathrm{CO}_{2}$ in Water as the Solvent. ACS Energy Letters. 2017;2:1395-9.

[29] Maurin A, Robert M. Catalytic $\mathrm{CO}_{2}$-to-CO conversion in water by covalently functionalized carbon nanotubes with a molecular iron catalyst. Chemical Communications. 2016;52:12084-7.

[30] Zhu M, Chen J, Huang L, Ye R, Xu J, Han Y-F. Covalently Grafting Cobalt Porphyrin onto Carbon Nanotubes for Efficient $\mathrm{CO}_{2}$ Electroreduction. Angewandte Chemie International Edition.

2019;58:6595-9.

*[31] Hu X-M, Rønne MH, Pedersen SU, Skrydstrup T, Daasbjerg K. Enhanced Catalytic Activity of Cobalt Porphyrin in $\mathrm{CO}_{2}$ Electroreduction upon Immobilization on Carbon Materials. Angewandte Chemie International Edition. 2017;56:6468-72.

Example of thorough comparison of catalytic performances for a molecular $\mathrm{CO}_{2}$ catalyst between homogeneous and supported conditions. This work shows the effectiveness of simple immobilisation strategies relying on weak catalyst-support interactions.

[32] Lin S, Diercks CS, Zhang Y-B, Kornienko N, Nichols EM, Zhao Y, R. Paris AR, Kim D, Yang P, Yaghi $\mathrm{OM}$, Chang $\mathrm{CJ}$. Covalent organic frameworks comprising cobalt porphyrins for catalytic $\mathrm{CO}_{2}$ reduction in water. Science. 2015;349:1208-13.

[33] Diercks CS, Lin S, Kornienko N, Kapustin EA, Nichols EM, Zhu C, Zhao Yingbo, Chang CJ, Yaghi OM. Reticular Electronic Tuning of Porphyrin Active Sites in Covalent Organic Frameworks for Electrocatalytic Carbon Dioxide Reduction. J Am Chem Soc. 2018;140:1116-22.

[34] Wang Y-R, Huang Q, He C-T, Chen Y, Liu J, Shen F-C, et al. Oriented electron transmission in polyoxometalate-metalloporphyrin organic framework for highly selective electroreduction of $\mathrm{CO}_{2}$. Nature Communications. 2018;9:4466. 
[35] Matheu R, Gutierrez-Puebla E, Monge MÁ, Diercks CS, Kang J, Prévot MS, Pei X, Hanikel N, Zhang $B$, Yang P,Yaghi OM. Three-Dimensional Phthalocyanine Metal-Catecholates for High Electrochemical Carbon Dioxide Reduction. J Am Chem Soc. 2019;141:17081-5.

[36] Corbin N, Zeng J, Williams K, Manthiram K. Heterogeneous molecular catalysts for electrocatalytic $\mathrm{CO}_{2}$ reduction. Nano Research. 2019;12:2093-125.

[37] Bohra D, Chaudhry JH, Burdyny T, Pidko EA, Smith WA. Modeling the electrical double layer to understand the reaction environment in a $\mathrm{CO}_{2}$ electrocatalytic system. Energy \& Environmental Science. 2019;12:3380-9.

* [38] Mahmood MN, Masheder D, Harty CJ. Use of gas-diffusion electrodes for high-rate electrochemical reduction of carbon dioxide. II. Reduction at metal phthalocyanine-impregnated electrodes. Journal of Applied Electrochemistry. 1987;17:1223-7.

In this avant-garde work, molecular catalysts were immobilised at carbon material (gas diffusion electrode) leading to high current density and selectivity for $\mathrm{CO}_{2}$ reduction.

[39] Furuya N, Koide S. Electroreduction of carbon dioxide by metal phthalocyanines. Electrochimica Acta. 1991;36:1309-13.

[40] Sonoyama N, Kirii M, Sakata T. Electrochemical reduction of $\mathrm{CO}_{2}$ at metal-porphyrin supported gas diffusion electrodes under high pressure $\mathrm{CO}_{2}$. Electrochemistry Communications. 1999;1:213-6. * [41] Ren S, Joulié D, Salvatore D, Torbensen K, Wang M, Robert M, Berlinguette CP. Molecular electrocatalysts can mediate fast, selective $\mathrm{CO}_{2}$ reduction in a flow cell. Science. 2019;365:367-9.

Molecular catalysts based on earth abundant metals can rival state-of-the art noble metal electrocatalysts for $\mathrm{CO}_{2}$-to-CO conversion in electrolyzers.

[42] Li YC, Yan Z, Hitt J, Wycisk R, Pintauro PN, Mallouk TE. Bipolar Membranes Inhibit Product Crossover in $\mathrm{CO}_{2}$ Electrolysis Cells. Advanced Sustainable Systems. 2018;2:1700187.

[43] Wang M, Torbensen K, Salvatore D, Ren S, Joulié D, Dumoulin F, Mendoza D, Lassalle-Kaiser B, Işci $\mathrm{U}$, Berlinguette $\mathrm{CP}$, Robert $\mathrm{M}$. $\mathrm{CO}_{2}$ electrochemical catalytic reduction with a highly active cobalt phthalocyanine. Nature Communications. 2019;10:3602.

[44] Lu X, Wu Y, Yuan X, Huang L, Wu Z, Xuan J, Wang Y, Wang H. High-Performance Electrochemical $\mathrm{CO}_{2}$ Reduction Cells Based on Non-noble Metal Catalysts. ACS Energy Letters. 2018;3:2527-32.

[45] Torbensen K, Han C, Boudy B, von Wolff N, Bertail C, Braun W, Robert M. Iron Porphyrin Allows Fast and Selective Electrocatalytic Conversion of $\mathrm{CO}_{2}$ to $\mathrm{CO}$ in a Flow Cell. Chemistry - A European Journal. 2020;26:3034-8.

[46] Ringe S, Clark EL, Resasco J, Walton A, Seger B, Bell AT, Chan K. Understanding cation effects in electrochemical $\mathrm{CO}_{2}$ reduction. Energy \& Environmental Science. 2019;12:3001-14.

[47] Dinh C-T, García de Arquer FP, Sinton D, Sargent EH. High Rate, Selective, and Stable Electroreduction of $\mathrm{CO}_{2}$ to $\mathrm{CO}$ in Basic and Neutral Media. ACS Energy Letters. 2018;3:2835-40.

[48] Verma S, Hamasaki Y, Kim C, Huang W, Lu S, Jhong H-RM, Gewirth AA, Fujigaya T, Naotoshi N, Kenis PJA. Insights into the Low Overpotential Electroreduction of $\mathrm{CO}_{2}$ to $\mathrm{CO}$ on a Supported Gold Catalyst in an Alkaline Flow Electrolyzer. ACS Energy Letters. 2018;3:193-8.

[49] Dinh C-T, Burdyny T, Kibria MG, Seifitokaldani A, Gabardo CM, García de Arquer FP, Kiani A, Edwards JP, De Luna P, Bushuyev OS, Zou C, Quintero-Bermudez R, Pang Y, Sinton D, Sargent EH. $\mathrm{CO}_{2}$ electroreduction to ethylene via hydroxide-mediated copper catalysis at an abrupt interface. Science. 2018;360:783-7.

[50] Yang H, Lin Q, Zhang C, Yu X, Cheng Z, Li G, Hu Q, Ren X, Zhang Q, Liu J, He C. Carbon dioxide electroreduction on single-atom nickel decorated carbon membranes with industry compatible current densities. Nature Communications. 2020;11:593. 